\title{
Sistem Pembayaran UKT Online Bagi Mahasiswa Politeknik Negeri Sriwijaya Berbasis Android
}

\author{
Dinda Amaniska ${ }^{1}$,Lindawati², Martinus Mujur Ros $^{3}$ \\ Politeknik Negeri Sriwijaya \\ Jalan Srijaya Negara, Bukit Besar, Palembang \\ ddindaamaniska@gmail.com
}

\begin{abstract}
The design of online UKT payment applications is based on the writer's desire to help Sriwijaya Polytechnic students in facilitating several daily support activities with an easier and more practical process, especially in this case related to online UKT payments. Thus the author intends to design an application online UKT payment system which in this study the author uses several programming languages such as Java, PHP, and My SQL then supported by the use of the waterfall method through the stages of design, modeling, construction, and submission of the system to users which ends with the stages of device usage in the final results The author uses this waterfall method hoping to minimize errors because as we know this method uses the one by one phase development process. The completion of this application is expected to be useful in the community, especially student students. i Sriwijaya State Polytechnic in making online UKT payments that can be used on their respective smartphones
\end{abstract}

Keywords: Payment, UKT, Java, XAMPP, MySQL

\begin{abstract}
Abstrak
Perancangan aplikasi pembayaran UKT online didasari atas keinginan penulis untuk membantu mahasiswa mahasiswi Politeknik Negeri Sriwijaya dalam mempermudah melakukan beberapa kegiatan penunjang sehari-hari dengan proses yang lebih mudah dan praktis terutama dalam hal ini berkaitan dengan pembayaran UKT online.Dengan demikian penulis berniat untuk merancang sebuah aplikasi sistem pembayaran UKT online yang dalam penelitian ini penulis menggunakan beberapa bahasa pemprograman seperti Java, PHP dan My SQL kemudian ditunjang dengan penggunaan metode waterfall melalui tahapan perancangan, permodelan, konstruksi serta penyerahan sistem ke para pengguna yang diakhiri dengan tahapan penggunaan perangkat pada hasil akhir. Penulis menggunakan metode waterfall ini berharap untuk memperkecil kesalahan karena seperti yang kita ketahui metode ini menggunakan proses pengembangan fase one by one.Rampungnya aplikasi ini diharapkan dapat berguna dengan baik dikalangan masyarakat terutama mahasiswa mahasiswi Politeknik Negeri Sriwijaya dalam melakukan pembayaran UKT online yang dapat digunakan pada smartphone mereka masing-masing.
\end{abstract}

Kata Kunci: Pembayaran, UKT, Java, XAMPP, MySQL

\section{PENDAHULUAN}

Dengan seiringnya perkembangan zaman yang didukung oleh perkembangan teknologi dan komunikasi, gaya hidup masyarakat global perlahan makin berubah 
menuju ke arah yang lebih praktis dan efisien. Seperti merubah hal-hal yang bersifat konvensional, menjadi serba online dalam melakukan kegiatan sehari-hari. Aktifitas online dapat berupa pembayaran online (e-Payment), transportasi online, berbelanja online, dan masih banyak lagi kegiatan penunjang kehidupan yang sudah bisa dilakukan secara online. E-Payment merupakan sistem pembayaran online yang menggunakan fasilitas internet sebagai sarana perantara. Saat ini banyak perusahaan yang memfasilitasi dengan memberikan jaminan keamanan transaksi e-Payment[1]. Demi menjamin keamanan transaksi tersebut, perusahaan yang menjadi perantara akan bekerja sama dengan sejumlah lembaga perbankan untuk mulai memfasilitasi e-payment secara aman, cepat dan praktis[1]. Dengan adanya kemudahan inilah yang membuat kaum milineal atau kalangan anak muda khususnya, sangat menyukai semua hal yang berkaitan dengan sistem online.

Sistem online saat ini sudah banyak diterapkan diberbagai bidang salah satunya di lembaga-lembaga pendidikan seperti Perguruan Tinggi. Di Perguruan Tinggi sistem online ini mencakup penggunaan metode pembelajaran online, dan pembayaran online (e-Payment).

Politeknik Negeri Sriwijaya merupakan salah satu Perguruan Tinggi yang terdapat di Indonesia yang masih menerapkan sistem pembayaran UKT (Uang Kuliah Tetap) yang dilakukan secara konvensional. UKT merupakan salah satu syarat untuk memenuhi persyaratan registrasi pada semester selanjutnya. Biasanya mahasiswa Politeknik Negeri Sriwijaya melakukan pembayaran UKT dengan cara melakukan penyetoran tunai UKT, yang akan dibayarkan dengan perusahaan Perbankan yang bekerja sama dengan Politeknik Negeri Sriwijaya.

Dalam hal ini, pembayaran UKT hanya bisa dilakukan pada Bank Mandiri (kantor pusat) yang berada di depan Kantor PLN Di Jalan Kapten A.Rivai Palembang, yang telah ditetapkan sebagai tempat penyetoran tunai UKT dari mahasiswa Politeknik Negeri Sriwijaya.

Hal ini menimbulkan kesulitan untuk menjangkau jarak Bank Mandiri tersebut, serta membutuhkan waktu yang cukup lama untuk melakukan antrean di Bank Mandiri apalagi ketika melakukan pembayaran pada jam-jam kerja. Kemudian pengisian form penyetoran tunai yang masih dilakukan secara manual yang terkadang banyak terjadinya kesalahan dalam penulisan, dan kejadian hilangnya kertas form penyetoran tunai yang berfungsi sebagai bukti pembayaran fisik (manual). Serta perlunya pengaksesan kembali ke pihak bank apabila suatu waktu bukti pembayaran tersebut diminta oleh pihak Polsri. Tidak hanya faktor diatas terkadang akibat susahnya jangakauan untuk ke kantor pusat Bank Mandiri yang ada di kota Palembang membuat beberapa kejadian seperti keterlambatan pembayaran UKT.

\section{METODOLOGI PENELITIAN}

a. Metode Diskusi

Yaitu melakukan diskusi dan konsultasi kepada dosen pembimbing pra TA (tugas akhir) mengenai pembahasan teori dan permasalahan yang ditemui ketika proses pengerjaan laporan yang akan dibuat. 


\section{b. Metode Observasi}

Membuat percobaan percobaan melalui panduan pada penelitian yang telah dilakukan sebelumnya menggunakan software yang akan digunakan pada pembuatan aplikasi.

c. Metode Perancangan

Tahapan pembuatan aplikasi yang didukung dengan beberapa bahasa pemprograman berupa JavaScript, PHP, MySQL berbasis android, dimana desain aplikasi pada tahap ini penulis memberikan gambaran melalui flowchart.

d. Studi Literatur

Penulis mendapatkan informasi bersifat teoritis berdasarkan buku-buku, artikel, penelitian yang telah dilakukan sebelumnya beserta jurnal yang tersedia

\section{HASIL DAN PEMBAHASAN}

Pada penelitian ini menghasilkan aplikasi yang terintegrasi secara online dengan system informasi berbasis web yang berfungsi sebagai media untuk memudahkan dalam melakukan proses pembayaran UKT mahasiswa Politenik Negeri sriwijaya secara online sehingga membuat proses pembayaran UKT dapat dilakukan dalam secara efektif dan efisien.

\subsection{Tampilan Dari Setiap Halaman Yang Ada Pada Aplikasi}

a. Tampilan Localhost

Localhost adalah server lokal yang ada padai komputer. Localhost adalah hostname dari komputer itu sendiri. Localhost dapat diakses ketika ada web server yang berjalan. Locallhost ini berisi table-tabel yang digunakan untuk membuat aplikasi tersebut. Tampilan halaman localhost dapat dilihat pada gambar dibawah ini :

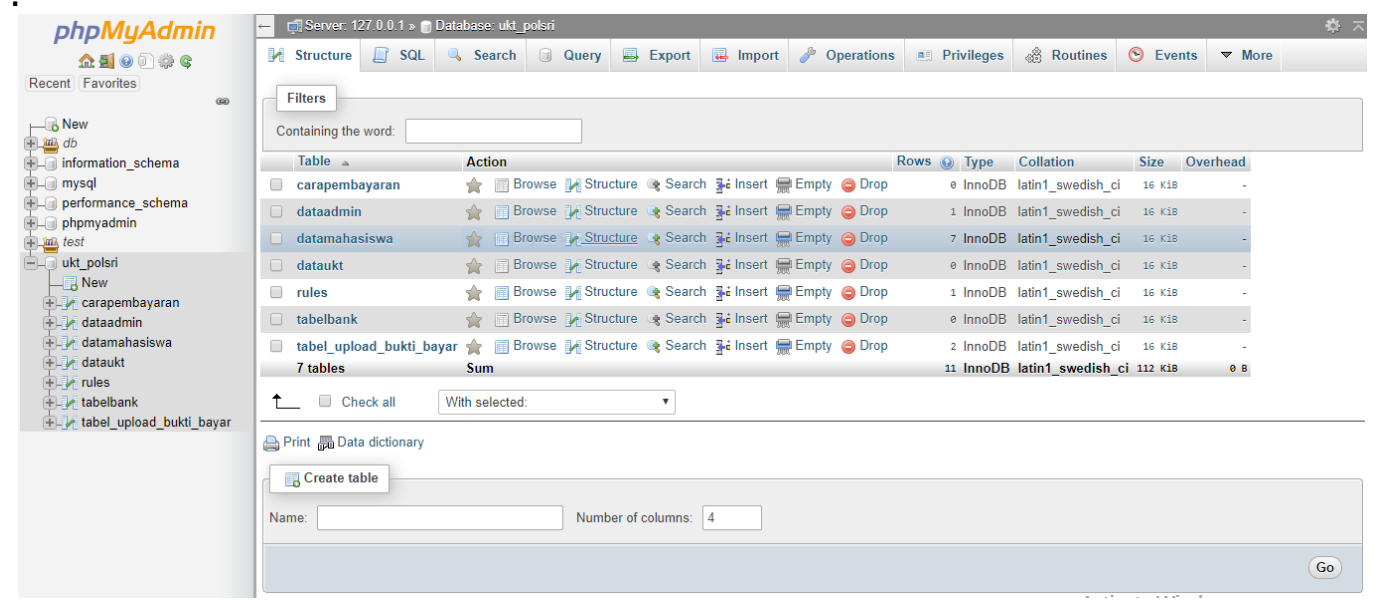

Gambar 1. Tampilan PHP MyAdmin

b. Tampilan Halaman Android Studio

Pada halaman ini merupakan platform untuk membuat code aplikasi pada android dengan menggunakan bahasa pemograman java dan xml. Bahasa program 
java digunakan untuk membuat perintah kerja aplikasi sedangkan bahasa program xml digunakan untuk membuat layout aplikasi yang akan dibuat.

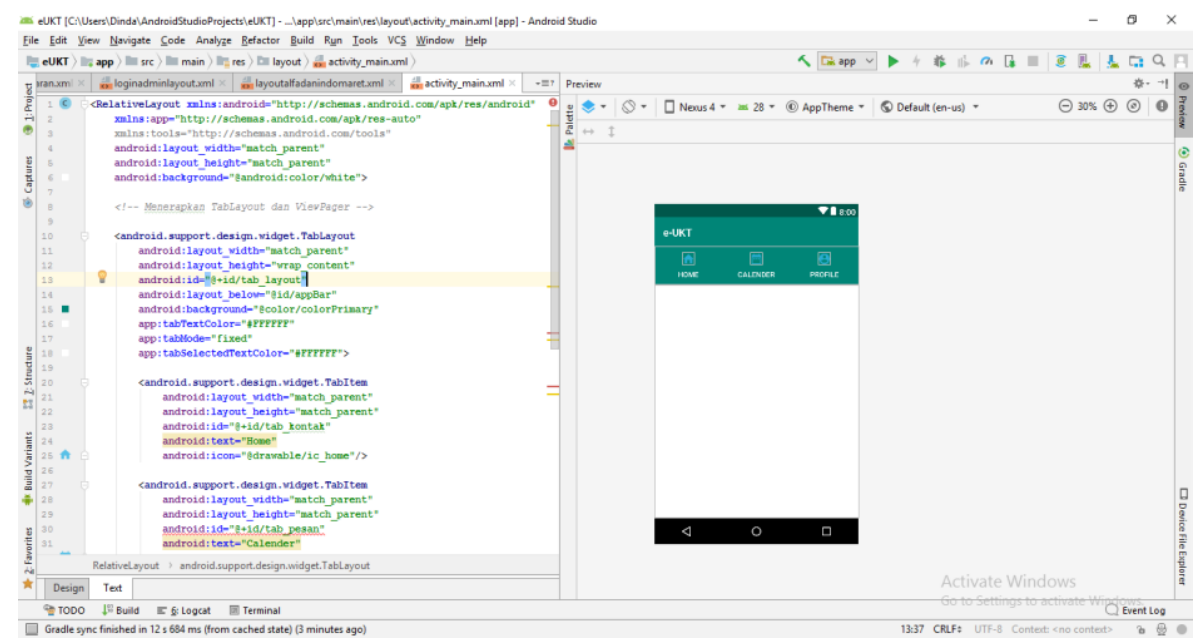

Gambar 2. Tampilan Pada Android Studio

c. Tampilan Awal Aplikasi Pada Web

Ini merupakan tampilan awal pada aplikasi yang dibuat dimana halaman ini memuat menu login baik dari sisi admin dan mahasiswa.

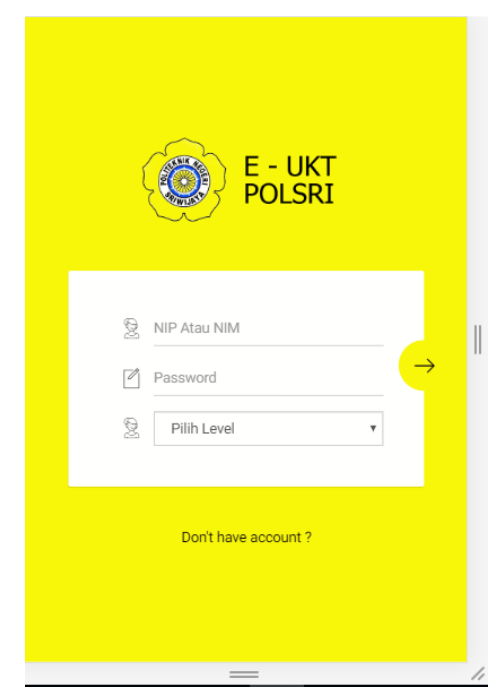

Gambar 3. Tampilan Awal Aplikasi E-UKT

d. Tampilan Register Pada Aplikasi

Pada halaman selanjutnya merupakan tampilan register bagi mahasiswa ataupun admin yang belum melakukan register untuk membuat akun terlebih dahulu dengan memilih "don't have account" pada menu login. Dan melakukan register sesuai dengan biodata mereka masing-masing 


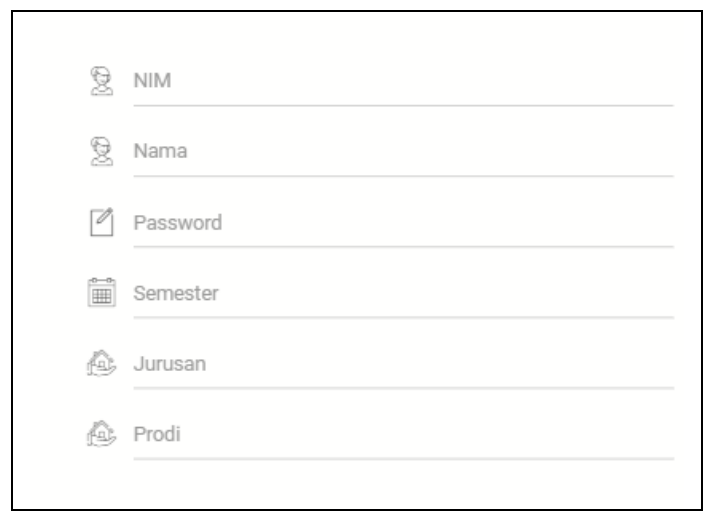

Gambar 4. Tampilan Register Pada Aplikasi E-UKT

e. Tampilan Home Pada Admin

Pada halaman Home di Sisi Admin berisikan fungsi update untuk memperbarui informasi mengenai pembayaran UKT tanggal mulai dan tanggal akhir pembayaran. Kemudian pada halamn ini juga berisi inromasi mahasiswa yang telah melakukan proses login untuk melakukan pembayaran.

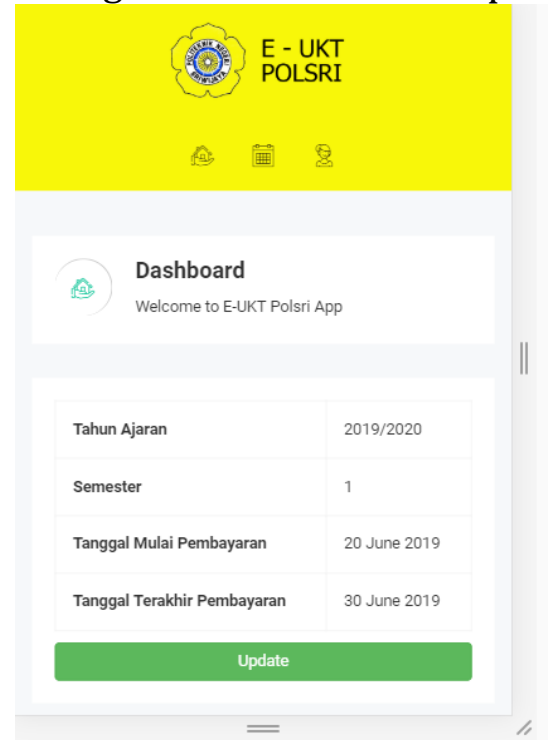

\section{Gambar 5. Tampilan Home Pada Sisi Admin}

f. Tampilan Profile Pada Admin

Halaman ini merupakan tampilan profile yang berisikan biodata admin 


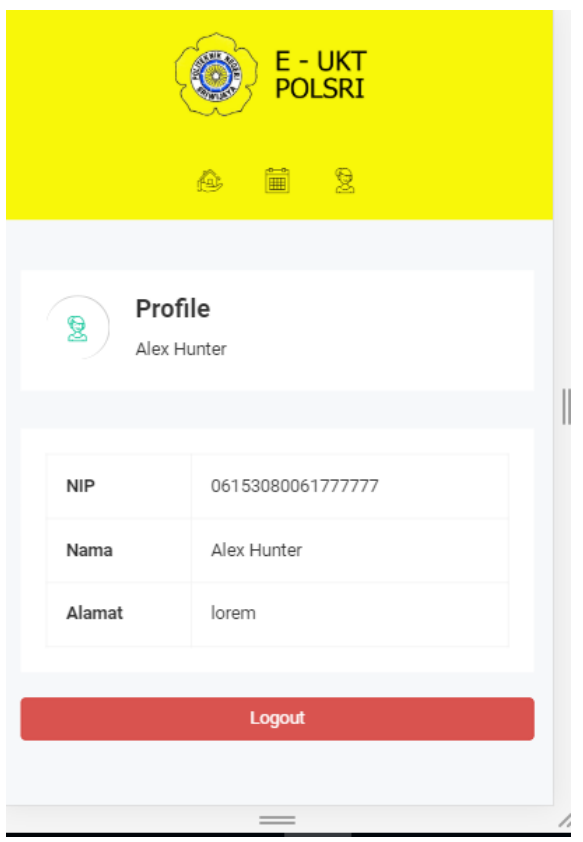

Gambar 6. Tampilan Menu Profile Pada Sisi Admin

g. Tampilan Menu Calender Pada Aplikasi

Halaman ini merupakan menu kalender untuk mngetahui informasi update mahasiswa yang sudah melakukan pembayaran sesuai tanggal yang dipilih oleh admin

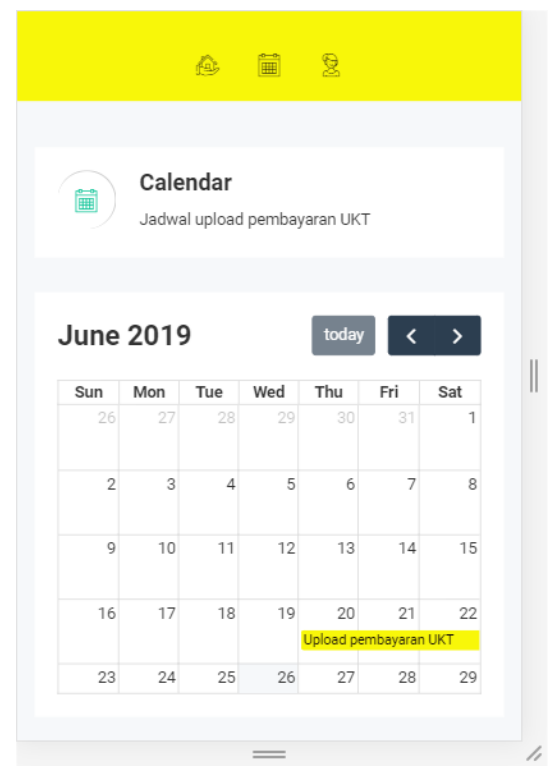

Gambar 7. Tampilan Menu Calender Pada Admin

h. Tampilan Data UKT Mahasiswa Pada Aplikasi

halaman ini merupakan halaman yang berisi daftar mahasiswa yang telah melakukan registrasi dan untuk melakukan pembayaran mahasiswa harys mendapat akses nominal sesuai dengan UKT yang dibayarkan. 
Jurnal Riset Sistem Informasi Dan Teknik Informatika (JURASIK)

Volume (4) Juli 2019, pp 134-141

ISSN: 2527-5771/EISSN: 2549-7839

http://tunasbangsa.ac.id/ejurnal/index.php/jurasik

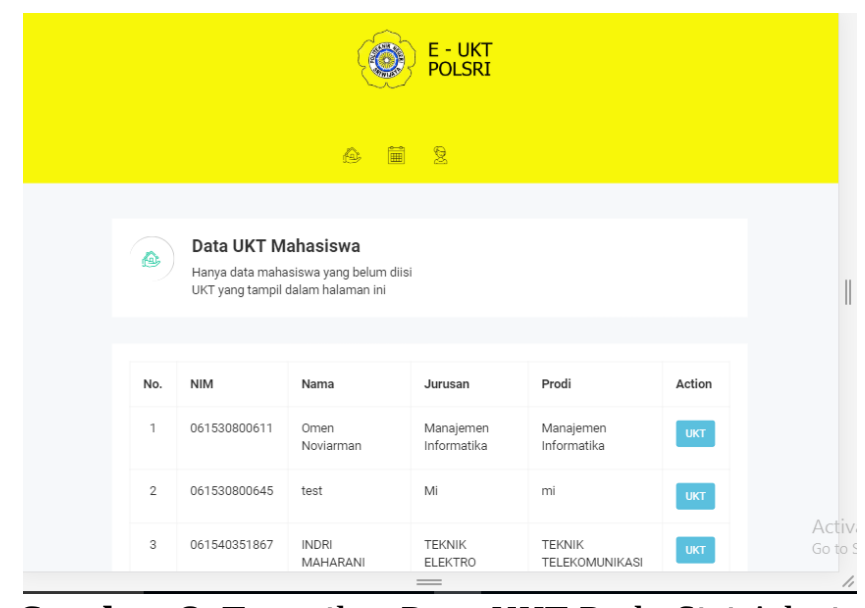

Gambar 8. Tampilan Data UKT Pada Sisi Admin

i. Tampilan Pada Sisi Mahasiswa

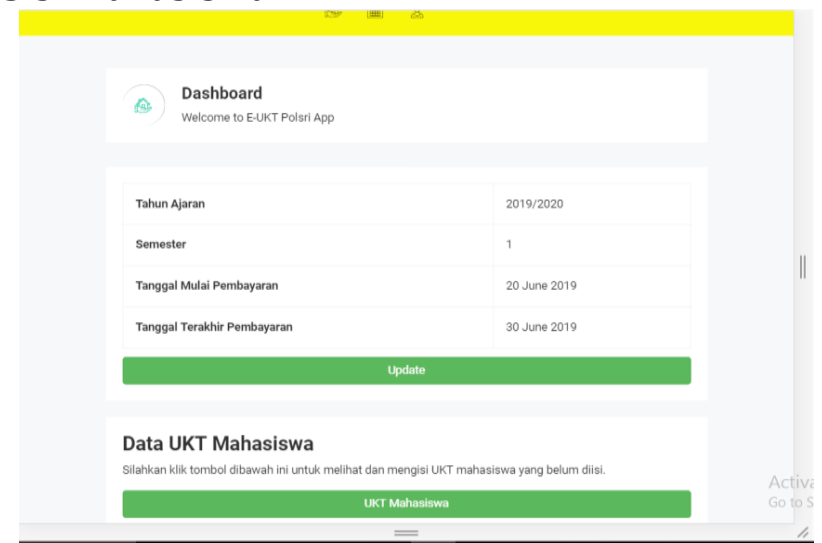

Gambar 9. Tampilan Home Pada Sisi Mahasiswa

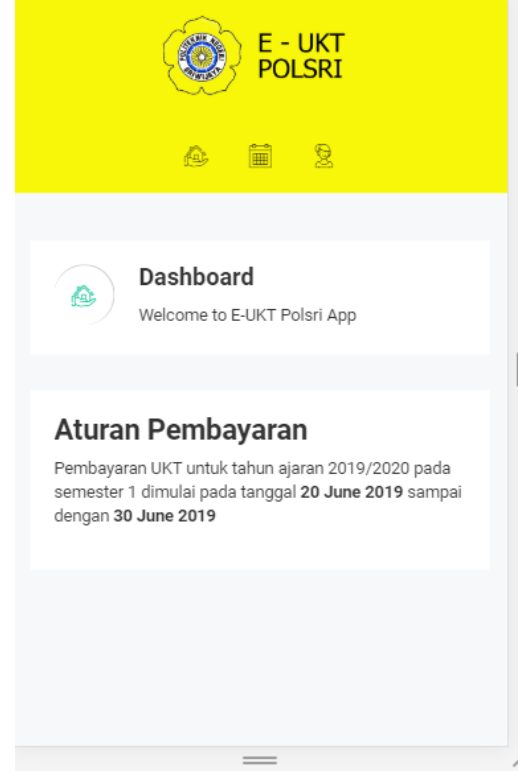

Gambar 10. Tampilan Aturan Pembayaran

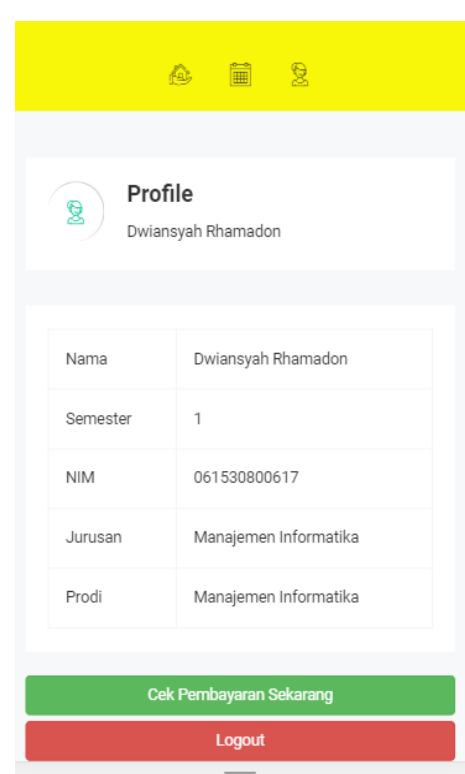

Gambar 11. Tampilan menu Profile 


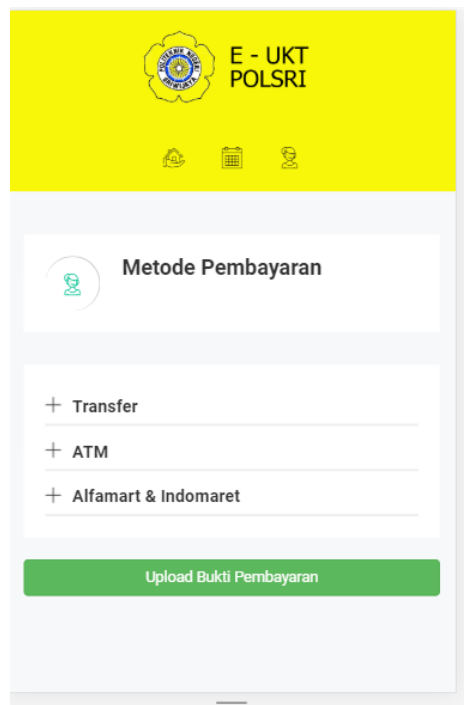

Gambar 12. Tampilan Metode Pembayaran

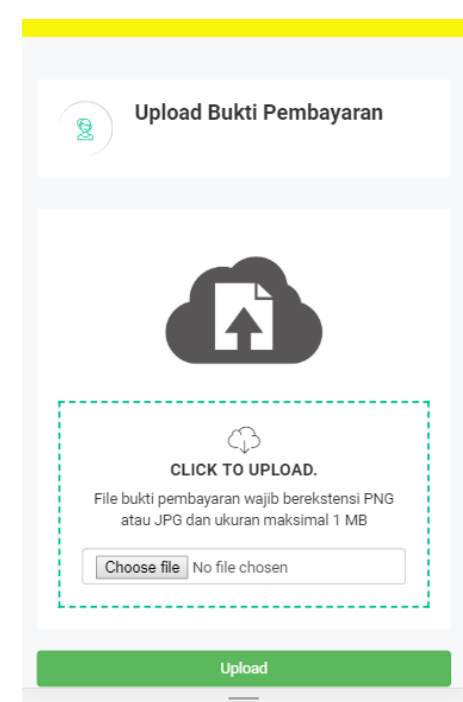

Gambar 13. Tampilan Bukti Upload

\section{SIMPULAN}

Pada penelitian tugas akhir ini, akan dilakukan Rancang Bangun aplikasi Pembayaran Online UKT Politeknik Negeri Sriwijaya Dengan Menggunakan Metode Waterfall, dimana hasil rancangan yang diinginkan yaitu berupa keberhasilan dalam melakukan pembayaran UKT yang dilakukan secara online. Dengan rancangan awal ini, diharapakan aplikasi dapat terselesaikan sesuai waktu yang ditentukan dan nantinya dapat berguna untuk penggunaan pribadi maupun secara umum terkhusus teman teman mahasiswa/mahasiswi Politeknik Negeri Sriwijaya dan pihak tata usaha selaku admin di Politeknik Negeri sriwijaya

\section{DAFTAR PUSTAKA}

[1] E Madayanto - Pengembangan Sistem E-Payment Berbasis Web Server- Jurnal Berkala Ilmiah Efisiensi, 2015 - ejournal - unsrat.ac.id https : // ejournal.unsrat.ac.id diakses pada 23 Desember 2018

[2] Kusrini., dan Kunoyo, Andri, 2007, Tuntunan Praktis Membangun Sistem Informasi Akuntansi dengan Visual Basic dan Microsoft SQL Server https: rancang-bangun-website-ecommerce-pada-b-726e9450 diakses pada 23 Desember 2018

[3] Versi Android Dan Fiturnya https://de-tekno.com/2015/11/versi-android-dan-fiturfiturnya/ diakses pada 23 Desember 2018

[4] T Lystiorini - Jurnal Teknik Mesin, Teknik Elektro dan Sistem Operasi - PERANCANGAN MOBILE LEARNING MATA KULIAH SISTEM OPERASI BERBASIS ANDROID jurnal.umk.ac.id https://jurnal.umk.ac.id/index.php/simet/article/view/85/0 diakses pada 23 Desember 2018

[5] T Ramadhan, VG Utomo - Sistem informasi , 2014 - RANCANG BANGUN APLIKASI MOBILE UNTUK NOTIFIKASI JADWAL KULIAH BERBASIS ANDROID (STUDI KASUS : STMIK PROVISI SEMARANG) ejurnal provisi.ac.id http://ejurnal.provisi.ac.id/index.php/JTIKP/article/view/93 diakses pada 23 Desember 2018 